\title{
Audit of caesarean deliveries in a tertiary care hospital of northern Andhra Pradesh using modified Robson criteria
}

\author{
Prabhavathi V. ${ }^{1}$, Krishnamma B. ${ }^{1}$, Prasad D. K. V. ${ }^{2}$, Bhavya K. ${ }^{1}$, Satyavathi R. ${ }^{1 *}$
}

${ }^{1}$ Department of Obstetrics and Gynecology, NRIIMS, Sangivalasa, Andhra Pradesh, India
${ }^{2}$ Department of Biochemistry, NRIIMS, Sangivalasa, Andhra Pradesh, India

Received: 08 May 2018

Accepted: 30 May 2018

\section{*Correspondence:}

Dr. Satyavathi R,

E-mail: drprasaddkv@yahoo.co.in

Copyright: () the author(s), publisher and licensee Medip Academy. This is an open-access article distributed under the terms of the Creative Commons Attribution Non-Commercial License, which permits unrestricted non-commercial use, distribution, and reproduction in any medium, provided the original work is properly cited.

\begin{abstract}
Background: Today, there is an increased trend in the incidence of caesarean section (CS) rate worldwide particularly in India, even with the lack of evidence supporting considerable maternal and perinatal benefits with higher CS rates. The main objective of our study was to find the incidence of CS rate, auditing the data on the basis of modified Robson criteria, factors responsible for the most common group, to know the changing trends of CS and finally put forth the strategies to reduce CS rate.

Methods: This is a retrospective study of 472 CS cases carried out in a tertiary care hospital during the year 2016. All the cases were grouped according to the modified Robson criteria and the data was analyzed. The data were grouped into 3 different slots of 4 months each (FF = first four months; $\mathrm{MF}=$ middle four months and $\mathrm{LF}=$ last four months of the year 2016).

Results: A significant increasing trend was observed in the groups of $2 \mathrm{~B}$ and $5 \mathrm{C}$ where as a significant decreasing trend was noticed in $6 \mathrm{C}$ and $7 \mathrm{C}$. The most common indications for caesarean delivery were cephalo-pelvic disproportion (CPD) (28\%) and fetal distress (22\%) in group 1 whereas in group 2A CPD, fetal distress and failed induction were found to be $12 \%, 24 \%$ and $30 \%$ respectively.

Conclusions: The change in trend has been noticed in the last few months particularly in $2 \mathrm{~B}$ and 5C groups suggesting that there is a change in the attitude of obstetricians in conducting caesarean deliveries before the onset of labour rather than performing CS after the onset of labour. Targeting 2B along with 5C would help our efforts in reducing the CS rate.
\end{abstract}

Keywords: Caesarean section rate, Data auditing, Modified Robson criteria, Trend

\section{INTRODUCTION}

Today there is an increased trend in the incidence of caesarean section (CS) rate worldwide particularly in middle- and high income countries, even with the lack of evidence supporting considerable maternal and perinatal benefits with CS rates higher than a certain threshold.

The ideal CS rate should be between $10-15 \%$ as WHO recommended and was an accepted norm until $2014 .^{1}$ Although CS is a life saving procedure for both mother and baby, the incidence of neonatal mortality and morbidity did not decrease with the increase in CS rates.

The following reasons have been designated for the rise of CS rates include fear of medico-legal issues, increasing maternal request, increasing malpractice pressure, convenience of scheduled deliveries as well as economic, cultural and organizational factors.

However, ICMR task force study stated after considering data from 30 teaching institutions that the most frequent 
indication for the primary CS would be CPD (52.9\%), fetal distress $(25.8 \%)$ and severe PIH/eclampsia (5\%). ${ }^{2}$

In 2015, with reference to CS rates the WHO issued an official statement and promoting the use of the Robson classification as a tool for optimizing the CS rate at health facilities. $^{3}$

A systematic review and population based study conducted by WHO stated that CS rates not more than $10-15 \%$ is coupled with low maternal, neonatal and infantile mortality. ${ }^{4}$

The CS should be prioritized according to maternal preferences, general risks and benefits of CS, complications associated with CS like uterine rupture and perinatal mortality and morbidity. ${ }^{5}$

In general, $\mathrm{CS}$ is more valuable to health care system and is associated with increased risk for both mother and baby. It has the potential to complicate subsequent pregnancies as well as long-term effects that are still being investigated. ${ }^{6}$ The complications such as uterine rupture, abnormalities in placental attachment to uterus eg. placenta accreta and percreta, which were strangely rare earlier, are now becoming very common obstetric emergencies. ${ }^{7}$

The vulnerability of uterine rupture in previous CS cases could be due to the relative weakness of the uterine wall at the point of scarring.

The consequence of placental implantation over or adjacent to scarring so that the placenta invades the uterine muscle more deeply which results in the formation of placenta accrete and percreta. And, this is assumed to occur since the scarred tissue from prior CS has a less healthy blood supply and abnormal architecture both at the tissue and cellular level as well.

The CS rates vary significantly by geographical region, which range from $25-35 \%$ among States, with the highest being south eastern United States. ${ }^{8}$ According to recent data from 150 countries, Latin America and Caribbean region are found to have the highest CS rates and Africa being the least with $7.3 \%$.

In Asia, the highest CS rate was observed in Turkey, Georgia and China of $39.5 \%, 32.9 \%$ and $31.8 \%$ respectively. ${ }^{9}$ In India, the average rate of CS in 1992 was $2.9 \%$, and has been increased to $17.2 \%$ in 2015 ranging from $5.8 \%$ in Nagaland to $58 \%$ in Telangana. ${ }^{10,11}$

It has been observed from an ecological study that CS rates higher than around $10 \%$ are not associated with substantial decreases in maternal and neonatal mortality rates. $^{12}$
Morbidity with CS is nearly 5-10 times higher than vaginal deliveries. ${ }^{13}$ Repeat CS contributes as major factor for common failures of CS in our population. The goals to reduce CS in the United States have become less indomitable.

The healthy people 2000 goal was to reduce CS rate to $15 \%$ of all births and the goal was revised to $15 \%$ for healthy people 2010 among women who had no prior CS and finally in healthy People 2020, the new target for CS is $23.9 \%$ among low-risk women in a first pregnancy with a full-term singleton pregnancy and vertex presentation. $^{14-16}$

The moving goal shows uncertainty in assessing the exact rate to enable the best possible maternal and infant outcomes and difficult to judge which intervention can safely reduce use of caesarean section. ${ }^{17,18}$

The main objectives of our study are to find the prevalence rate of $\mathrm{CS}$, auditing the data on the basis of modified Robson criteria, factors responsible for the most common group, to know the changing trends of CS and finally put forth the strategies to reduce CS rate.

\section{METHODS}

The present retrospective observational study has been carried out in the Department of Obstetrics and Gynecology, NRIIMS, Sangivalasa. All the women delivered by caesarean section from 1/1/2016 to $31 / 12 / 2016$ in antenatal ward were included for the study.

The obstetric information such as parity, mode of previous deliveries, previous CS indications, gestational age, onset of labour, spontaneous or induced labour was taken from all the women who underwent CS in our hospital. Patients were classified on the basis of indications for CS using modified Robson's criteria.

Indications for each CS were noted in the structured proforma prepared on the basis of modified Robson's criteria. A total of 472 cases were distributed according to the modified Robson's criteria and data was analysed.

To study the changes in trends, the data were grouped into three different slots of 4 months each (FF-1/1/2016 to $30 / 04 / 2016, \mathrm{n}=161$; and $\mathrm{MF}-1 / 05 / 2016$ to $31 / 08 / 2016$, $\mathrm{n}=127$ and $\mathrm{LF}-1 / 9 / 2016$ to $31 / 12 / 2016, \mathrm{n}=184$ ) to study the changes in the trends of caesarean births.

The changing trends notified were analyzed in each group on the basis of modified Robson's criteria and the data of FF, MF and LF was compared.

' $Z$ ' test was used to test the difference between the groups, to know the statistical significance and the pvalue of $<0.05$ was considered to be significant. 
Table 1: Description of modified Robson criteria.

\begin{tabular}{|c|c|}
\hline Group & Modified Robson \\
\hline 1 & Nullipara, singleton, cephalic, $\geq 37$ weeks, spontaneous labour \\
\hline $2 \mathrm{~A}$ & Nullipara, singleton, cephalic, $\geq 37$ weeks- Induced labour \\
\hline 2B & Nullipara, singleton, cephalic, $\geq 37$ weeks- Delivered by caesarean section before labour \\
\hline 3 & Multipara without previous uterine scar with single cephalic $\geq 37$ weeks in spontaneous labour \\
\hline 4A & Multipara without previous uterine scar with single cephalic $\geq 37$ weeks- Induced \\
\hline 4B & Multipara without previous uterine scar with single cephalic $\geq 37$ weeks- caesarean section before labour \\
\hline $5 \mathrm{~A}$ & All multipara with one previous uterine scar and single cephalic pregnancy $\geq 37$ weeks- Spontaneous labour \\
\hline 5B & All multipara with one previous uterine scar and single cephalic pregnancy $\geq 37$ weeks- Induced \\
\hline $5 \mathrm{C}$ & $\begin{array}{l}\text { All multipara with one previous uterine scar and single cephalic pregnancy } \geq 37 \text { weeks- Caesarean section } \\
\text { before labour }\end{array}$ \\
\hline 6A & All nullipara with singleton, breech pregnancy- Spontaneous labour \\
\hline 6B & All nullipara with singleton, breech pregnancy- Induced labour \\
\hline $6 \mathrm{C}$ & All nullipara with singleton, breech pregnancy- Caesarean section before labour \\
\hline $7 \mathrm{~A}$ & Multipara, singleton, breech pregnancy including women with previous caesarean section- Spontaneous labour \\
\hline 7B & Multipara, singleton, breech pregnancy including women with previous caesarean section-Induced labour \\
\hline 7C & $\begin{array}{l}\text { Multipara, singleton, breech pregnancy including women with previous caesarean section-Caesarean section } \\
\text { before labour }\end{array}$ \\
\hline $8 \mathrm{~A}$ & Multiple pregnancy including women with previous caesarean section- Spontaneous labour \\
\hline 8B & Multiple pregnancy including women with previous caesarean section- Induced labour \\
\hline $8 \mathrm{C}$ & Multiple pregnancy including women with previous caesarean section- Caesarean section before labour \\
\hline $9 \mathrm{~A}$ & $\begin{array}{l}\text { Women with singleton pregnancy with transverse or oblique lie including women with previous caesarean } \\
\text { section- Spontaneous labour }\end{array}$ \\
\hline 9B & $\begin{array}{l}\text { Women with singleton pregnancy with transverse or oblique lie including women with previous caesarean } \\
\text { section- Induced labour }\end{array}$ \\
\hline $9 \mathrm{C}$ & $\begin{array}{l}\text { Women with singleton pregnancy with transverse or oblique lie including women with previous caesarean } \\
\text { section- Caesarean section before labour }\end{array}$ \\
\hline $10 \mathrm{~A}$ & $\begin{array}{l}\text { Women with single cephalic pregnancy } \leq 36 \text { weeks gestation including previous caesarean section- } \\
\text { Spontaneous labour }\end{array}$ \\
\hline 10B & $\begin{array}{l}\text { Women with single cephalic pregnancy } \leq 36 \text { weeks gestation including previous caesarean section- Induced } \\
\text { labour }\end{array}$ \\
\hline $10 \mathrm{C}$ & $\begin{array}{l}\text { Women with single cephalic pregnancy } \leq 36 \text { weeks gestation including previous caesarean section- Caesarean } \\
\text { section before labour }\end{array}$ \\
\hline
\end{tabular}

\section{RESULTS}

During the study period, the total number of women delivered was 1312 , out of which by CS were 472 . The percentage of $\mathrm{CS}$ rate during this specified period was 35.9 .

The results of modified Robson's classification were depicted in Table 1. All the cases were divided into 3 group's viz. FF, MF, and LF on the basis of month of delivery during that year. The total number of CS cases in first 4 months (FF) was 161, the middle 4 months (MF) 127 and the last 4 months (LF) was 184. In the present study, all the cases were grouped according to the modified Robson's classification.

The distributions of cases in each group according to classification are depicted in Table 1. An increasing trend was observed in 2B group cases, where as a reducing trend was found in 1 group cases (Table 2).
In addition, the percentage of cases in $4 \mathrm{~B}$ group increased from 1.24 in FF to 1.63 in LF. An increasing trend was seen in 5C group and the percentage of group 5C cases in FF, MF and LF was 29.8\%, 34.64\% and $39.13 \%$ respectively (Table 2 ). However, the rate of $\mathrm{CS}$ in group $2(2 \mathrm{~A}+2 \mathrm{~B})$ and $5(\mathrm{~A}+\mathrm{B}+\mathrm{C})$ are unaffected (Table 3$)$.

A decreasing trend was observed in $6 \mathrm{C}$ group and the percentage of cases in the three studied groups was $2.48 \%, 1.57 \%$ and 1.08 respectively. Similarly, the reducing trend was also observed in $7 \mathrm{C}$ cases. The percentage of cases in $7 \mathrm{C}$ was $3.72 \%, 1.57 \%$ and $1.08 \%$ in FF, MF and LF respectively (Table 2).

On the contrary, in cases of 1 and 5A groups the trend was found to be decreasing from 27.9, 3.72 in FF to 20.6 and 2.17 in LF respectively (Table 2). No significant changes were noticed in 8,9 and 10 groups, however decreasing trend was found in $8 \mathrm{C}$ cases (Table 2). 
Table 2: Distribution of cases according to modified Robson criteria in each group during the year 2016.

\begin{tabular}{|c|c|c|c|c|c|c|}
\hline Group & $\begin{array}{l}\text { First } 4 \text { months } \\
(n=161)\end{array}$ & $\begin{array}{l}\text { Middle } 4 \text { months } \\
(\mathrm{n}=127)\end{array}$ & $\begin{array}{l}\text { Last } 4 \text { months } \\
(n=184)\end{array}$ & $\begin{array}{l}\text { FF vs MF } \\
\text { p-value }\end{array}$ & $\begin{array}{l}\text { MF vs LF } \\
\text { p-value }\end{array}$ & $\begin{array}{l}\text { FF vs LF } \\
\text { p-value }\end{array}$ \\
\hline 1 & $45(27.9)$ & $33(25.98)$ & $38(20.6)$ & 0.35 & 0.13 & $0.05^{*}$ \\
\hline $2 \mathrm{~A}$ & $12(7.45)$ & $4(3.14)$ & $8(4.34)$ & $0.05 *$ & 0.29 & 0.1 \\
\hline $2 B$ & $22(13.66)$ & $22(17.32)$ & $43(23.3)$ & 0.19 & 0.09 & $0.01 *$ \\
\hline 3 & 00 & $4(3.14)$ & $8(4.34)$ & $0.01 *$ & 0.29 & $0.003 *$ \\
\hline $4 \mathrm{~A}$ & $2(1.24)$ & 00 & $2(1.68)$ & 0.1 & 0.11 & 0.44 \\
\hline $4 \mathrm{~B}$ & $2(1.24)$ & $2(1.57)$ & $3(1.63)$ & 0.4 & 0.48 & 0.38 \\
\hline $5 \mathrm{~A}$ & $6(3.72)$ & $4(3.14)$ & $4(2.17)$ & 0.39 & 0.45 & 0.19 \\
\hline $5 \mathrm{~B}$ & 00 & 00 & 00 & & & \\
\hline $5 \mathrm{C}$ & $48(29.8)$ & $44(34.64)$ & $72(39.13)$ & 0.38 & 0.21 & $0.03 *$ \\
\hline $6 \mathrm{~A}$ & $2(1.24)$ & $4(3.14)$ & 00 & & & \\
\hline $6 \mathrm{~B}$ & 00 & 00 & 00 & & & \\
\hline $6 \mathrm{C}$ & $4(2.48)$ & $2(1.57)$ & $2(1.08)$ & & & - \\
\hline $7 \mathrm{~A}$ & $2(1.24)$ & 00 & 00 & & & \\
\hline $7 \mathrm{~B}$ & $2(1.24)$ & 00 & 00 & & & \\
\hline $7 \mathrm{C}$ & $6(3.72)$ & $2(1.57)$ & $2(1.08)$ & & & \\
\hline $8 \mathrm{~A}$ & $4(2.48)$ & 00 & 00 & & & \\
\hline $8 \mathrm{~B}$ & 00 & 00 & 00 & & & \\
\hline $9 \mathrm{~A}$ & $2(1.24)$ & 00 & 00 & & & \\
\hline $9 \mathrm{~B}$ & 00 & 00 & 00 & & & \\
\hline $9 \mathrm{C}$ & 00 & $2(1.57)$ & 00 & & & \\
\hline $10 \mathrm{~A}$ & 00 & 00 & 00 & & & \\
\hline $10 \mathrm{~B}$ & 00 & 00 & 00 & & & \\
\hline
\end{tabular}

$\mathrm{FF}=$ First Four months; MF=Middle Four months; LF=Last Four months; $\mathrm{p} \leq 0.05 *$ is significant

Table 3: Comparison of trends in nullipara and previous caesarean section.

\begin{tabular}{|llll|}
\hline Group & First 4 months $(\mathrm{n}=\mathbf{1 6 1})(\mathbf{3 4 . 1 \%})$ & Middle 4 months $(\mathrm{n}=\mathbf{1 2 7})(\mathbf{2 6 . 9 \% )}$ & Last 4 months $(\mathrm{n}=\mathbf{1 8 4})(\mathbf{3 9 \%})$ \\
\hline 1 & $45(27.9)$ & $33(25.98)$ & $38(20.6)$ \\
\hline 2A & $12(7.45)$ & $4(3.14)$ & $8(4.34)$ \\
\hline 2B & $22(13.66)$ & $22(17.32)$ & $43(23.3)$ \\
\hline 1+2A+2B & $79(49.01)$ & $59(46.44)$ & $49(48.24)$ \\
\hline 5A & $6(3.72)$ & $4(3.14)$ & $4(2.17)$ \\
\hline 5B & 00 & 00 & $72(39.13)$ \\
\hline 5C & $48(29.8)$ & $44(34.64)$ & $76(41.3)$ \\
\hline 5A+5B+5C & $54(33.52)$ & $48(37.78)$ & \\
\hline
\end{tabular}

\section{DISCUSSION}

It has been evidenced from literature that the importance of Modified Robson TGCS (Ten Group Classification System) in the efforts to reduce the CS rate. In fact, it is well-known that classification of the data of caesarean sections undertaken in any category of obstetric unit becomes a fundamental step towards these efforts. There is a steep increase in the rates of CS in the last three decades globally. A significant percentage of this rise was due to unnecessary operations attributable to nonevidence-based indications, professional convenience, maternal request, and over-medicalisation of childbirth. ${ }^{19}$ This is an important issue for health systems in many parts of the world as it causes long and short term health complications and the increased cost issues associated with caesarean births.

In 2014, ICMR task force study reported by considering 30 teaching medical institutions that the CS rate was found to be $28.1 \% .^{2}$ And also, according to National Family Health Survey-4 (NFHS-4) the average rate of CS from $2.9 \%$ in 1992 , has been increased to $17.2 \%$ in 2015 ranging from $5.8 \%$ in Nagaland to $58 \%$ in Telangana. ${ }^{11}$ In the present study, the prevalence of CS rate was found to be $35.9 \%$ which is almost identical to ICMR task force study.

In the present study, a significant decreasing trend was noticed in group 1 cases particularly when compared 
between first four months (FF) and last four months (LF). It could be due to the identification of cases that need CS and posting them for elective CS before labour.

Analysis of our data using modified Robson criteria enables us to target our efforts more specifically and effectively. And also it is very easy for us to know which subgroup of the CS shows the increasing or decreasing trend. A statistically significant increasing trend in group 2B (Table 2), particularly in the last 4 months of studied population (group LF) reveals that more cases of nulliparous women at term with cephalic presentation are undertaken for CS before the onset of labour than the spontaneous labour.

Generally, it is anticipated that the women who delivered vaginally earlier would deliver vaginally in future than the women needing a CS. In the present study, the increasing trend was noticed in $4 \mathrm{~B}$ group in the last 4 months (group LF) as compared to FF (first 4 months) as well as LF (last 4 months) (Table 2). The data suggests that multigravida even without previous history of CS were also taken for CS before the onset of labour and it might be possible due to lack of efficient nursing staff, non-evidence based indications and also professional convenience.

All nulliparous women were categorised under group 1, $2 \mathrm{~A}$ and $2 \mathrm{~B}$. It was noticed that a decreasing trend in cases of group 1 in the last 4 months (LF) as compared to FF and MF. On the contrary, the increasing trend in the cases of $2 \mathrm{~B}$ was also found. But, the rate of $\mathrm{CS}$ was increased from group 1 to $2 \mathrm{~B}$ which indicates that more number of nulliparous women was subjected to CS before the onset of labour. However, the rate of CS in nulliparous women (group 1, 2A and 2B) found to be unaffected (Table 3, Figure1). The proclivity of majority obstetricians to take a decision of CS before the onset of labour is to minimize risk of neonatal morbidity and mortality in the progression of labour. This contributes to the increasing trend of primary and repeat CS before the onset of labour.

Similarly, less caesarean section were found in 5A and $5 \mathrm{~B}$ as compared to $5 \mathrm{C}$ group. An increased trend was observed in $5 \mathrm{C}$ (Table 2), which signifies the change in the attitude of our obstetricians in favour of CS before the onset of labour rather than after the onset of labour. It is evidence from data, in groups $(2 \mathrm{~A}+2 \mathrm{~B})$ and $(5 \mathrm{~A}+5 \mathrm{~B}+5 \mathrm{C})$, the rate of $\mathrm{CS}$ in multiparous women was found to be unaffected although there is a significant change in sub groups (Table 3 and Figure1). It may also be true that more number of CS were also performed in multiparous cases having no history of previous CS for the same reasons. In addition to $2 \mathrm{~B}$ and $4 \mathrm{~B}$, targeting $5 \mathrm{C}$ definitely would help our efforts in reducing the CS rate.

In the present study, the total number of cases in group 6 (who are nullipara, singleton with breech pregnancy) was 14 , out of which 6 were in $6 \mathrm{~A}$ and 8 were in $6 \mathrm{C}$ where as no cases were in $6 \mathrm{~B}$. It was also found that a decreased trend in 6C cases of LF group as compared to FF and MF groups. This decreasing trend could be possible due to departmental policy as we allow breech pregnancies for assisted breech deliveries in selected cases. Although there is a lot of debate regarding the induction of labour for breech cases, it is a safe practice to avoid induction in breech deliveries.

The cases of twin pregnancy and abnormal presentations were included in group 8 and 9 respectively and we did not find much difference in both these groups. Similarly, in group 10 also no change was found in all preterm cases with cephalic presentation.

The WHO global survey revealed that the most common indications for caesarean section included repeat caesarean delivery (24.2\%), cephalo-pelvic disproportion CPD) $(22.6 \%)$, fetal distress $(20.5 \%)$, breech and other abnormal presentations (12.5\%).20 It has also been observed by an audit from United Kingdom that the top five indications for CS are fetal compromise (22\%) followed by failure to progress $(20 \%)$, repeat CS (14\%), breech $(11 \%)$ and maternal request $(7 \%) .{ }^{21}$ Among all, caesarean delivery on maternal request (CDMR) was one of the main indications for CS and has been on a rise (23\%), particularly in India as well and is ethically debatable. ${ }^{22}$ It is the most frequently cited reason for the increasing incidence of cesarean sections. Undoubtedly, it has been observed in recent years that an increase in mothers request for cesarean delivery on the basis of assumed advantages in the prevention of urinary and fecal incontinence, sexual dysfunction, and genital prolapse etc. compared to vaginal delivery. ${ }^{23}$ It has been noticed that relatively the minority of women ask for caesarean delivery, although the high CS rate is often attributed to increase in CDMR. The fear of spontaneous child birth (tocophobia) may also a major contributing factor for the request for elective caesarean section. ${ }^{24}$ The incidence of this condition is estimated between $6 \%$ and $10 \% .{ }^{24,25}$ In the present study, the incidence of CS rate was found to be $35.9 \%$ during the study period. Among the indications for caesarean delivery, the most common indications in the 1 group were CPD (28\%) and fetal distress $(22 \%)$ whereas in 2A group CPD, fetal distress and failed induction were found to be $12 \%, 24 \%$ and $30 \%$ respectively in the study group. Finally, it has been also observed from different cross-sectional studies that the association between CS rates and mortality outcomes of both mother and infant changed from $9 \%$ to $16 \%$ whereas no association exist above this threshold value. ${ }^{26}$

\section{CONCLUSION}

Auditing the data of CS by modified Robson criteria is the better way of classification to know the changing trends in CS rates. Present study showed increasing trend in group 2B (Nulliparous, singleton, term, vertex, not in labour) and $5 \mathrm{C}$ (repeat $\mathrm{CS}$ in mothers with previous CS) which needs to be reduced by allowing low risk patients to go into spontaneous labour, trial of scar in singleton 
pregnancies and encouraging vaginal birth after caesarean (VBAC) delivery. In addition, providing experienced hands with high quality midwifery, effective utilization of antenatal care and doctor's commitment is some of the effective ways to reduce the increasing CS rates.

\section{Funding: No funding sources}

Conflict of interest: None declared

Ethical approval: The study was approved by the Institutional Ethics Committee

\section{REFERENCES}

1. World Health Organization. "Appropriate Technology for Birth”. Lancet. 1985;326(8452):4367.

2. Dhillon BS, Chandhiok N, Bhatia BS, Coyaji KJ, Das MC, Das V, et al. Vaginal birth after caesarean section (VBAC) versus emergency caesarean section at teaching hospitals in India: an ICMR task force study. Int J Reprod Contracept Obstet Gynecol. 2014;3(3):592-7.

3. Hartmann K, Andrews J, Jerome R, Lewis R, Likis F, McKoy J, et al. Strategies to reduce cesarean birth in low-risk women. Agency Healthcare Res Qual (US) 2012; Rep. No. 12(13)-EHC128-EF.

4. Department of Reproductive Health and Research. WHO statement on Caesarean Section rates, 2015. World Health Organization, Geneva.

5. Sajjad R, Ali CA, Iqbal A, Sajjad N, Haq MZ. An audit of cesarean sections in Military Hospital Rawalpindi. Anaesth Pain and Intensive Care. 2014;18(2):172-5.

6. National Institutes of Health Consensus Development conference statement vaginal birth after caesarean: new insight. 2010;115(6):1279-95.

7. Blanchette $H$. The rising caesarean delivery rate in America: what are the consequences? Obstet Gynecol. 2011;118(3):687-90.

8. Menacker F, Hamilton BE. Recent trends in caesarean delivery in the United States. NCHS Data Brief. 2010;(35):1-8.

9. Betran AP, YE J, Moller AB, Zhang J. The increasing trend in caesarean section rates: global, regional and national estimates:1990-2014. PLoS ONE. 2016;11(2):e0148343.

10. International Institute for population Sciences, Mumbai. National Family Health Survey (NFHS-1) 1992-93.

11. International Institute for population Sciences, Mumbai. National Family Health Survey (NFHS-4) 2015-16 India Fact sheet; 2017.

12. Ye J, Zhang J, Mikolajczyk R, Torloni MR, Gulmezoglu AM, Betran AP. Association between rates of caesarean section and maternal and neonatal mortality in the 21 st century: a world-wide population based ecological study with longitudinal data. BJOG. 2016;123:745-53.

13. Baghianimoghadam MH, Zolghadar R, Moghadam BB, Darayi M, Jozy F. Related factors to choose normal vaginal delivery by mothers based on Health Belief Model. J Educ Health Promot. 2012;1:17.

14. National Centre for Health Statistics. Healthy People 2000 Final Review. Hyattsville, MD: Public Health Service; 2001.

15. U.S. Department of Health and Human Services. Healthy people 2010 2nd ed. With Understanding and improving health and objectives for improving health. 2 vols, Washington, DC: U.S. Government printing office; 2000.

16. U.S. Department of Health and Human Services. Healthy People 2020. Washington DC; 2011.

17. Cyr RM. Myth of the ideal cesarean section rate: commentary and historic perspective. Am J Obstet Gynecol. 2006;194(4):932-6.

18. Resnik R. Can a $29 \%$ cesarean delivery rate possibly be justified? Obstet Gynecol. 2006;107(4):752-4.

19. Robson M, Hartigan L, Murphy M. Methods of achieving and maintaining an appropriate caesarean section rate. Best Pract Res Clin Obstet Gynaecol. 2013;27:297-308.

20. Lumbiganon P, Laopaiboon M, Gulmezoglu AM, Souza JP, Taneepanichskul S, Ruyan P, et al. Method of delivery and pregnancy outcomes in Asia: the WHO global survey on maternal and perinatal health 2007-08. The Lancet. 2010;375(9713):490-9.

21. Thomas J, Paranjothy S. Royal College of Obstetricians and Gynaecologists, Clinical Effectiveness Support Unit. The National Sentinel Caesarean Section Audit Report. London. RCOG Press; 2001.

22. Mackenzie IZ, Cooke I, Annan B. Indications for cesarean section in a consultant unit over the decades. J Obstet Gynecol. 2003;23:233-8.

23. Mylonas I, Friese K. Indications for and risks of elective cesarean section. Dtsch Arztebl Int. 2015;112:489-95.

24. Sahlin M, Carlander-Klint AK, Hildingsson I, Wiklund I. First-timemothers' wish for a planned caesarean section: deeply rooted emotions. Midwifery. 2013;29:447-52.

25. Wiklund I. New guidelines for cesarean section on maternal request. Sex Reprod Healthc. 2012;3:97.

26. Betran AP, Torloni MR, Zhang J, Ye J, Mikolajczyk, Deneux-Tharaux C, et al. What is the optimal rate of caesarean section at population level? A systematic review of ecological studies. Reproductive Health. 2015;12:57.

Cite this article as: Prabhavathi V, Krishnamma B, Prasad DKV, Bhavya K, Satyavathi R. Audit of caesarean deliveries in a tertiary care hospital of northern Andhra Pradesh using modified Robson criteria. Int J Reprod Contracept Obstet Gynecol 2018;7:2796-801. 